FEATURE

Nick Barford

Office for National Statistics

\section{SUMMARY}

Workforce jobs (WFJ) is a quarterly measure of the number of jobs in the UK and the preferred measure of the change in jobs by industry. This article explains the processes and other causes of revisions on the WFJ, showing their impact on the series in terms of the revisions to levels and annual growth. The revisions are mainly due to benchmarking the shortterm series to the latest estimates from the Annual Business Inquiry for 2006 and 2007, and taking on reweighted Labour Force Survey inputs to WFJ.

\title{
Revisions to \\ workforce jobs: December 2008
}

$T$ he Office for National Statistics (ONS) released revisions to the workforce jobs (WFJ) series on 17 December 2008 in the Labour Market Statistics First Release (see ONS 2008a). WFJ is a quarterly measure of the number of jobs in the UK and is the preferred measure of the change in jobs by industry. It is the sum of employee jobs measured primarily by employer surveys, self-employment jobs from the Labour Force Survey (LFS), and government-supported trainees and HM Forces from administrative sources.

The revisions policy for WFJ is to open the series for revisions in December each year. The main causes of revisions this year are:

- benchmarking the short-term employee jobs series for Great Britain (GB) to the latest estimates from the Annual Business Inquiry (ABI1) for 2006 and 2007

- reweighted Labour Force Survey (LFS) inputs to WFJ from 1995Q1

- revisions to other sources, such as public sector employment and Northern Ireland jobs estimates.

Table 1 and Table 2 show the revisions to UK WFJ back to 1996. In total, the level of WFJ has been revised downwards by 18,000 ( 0.06 per cent) in June 2008 to $31,661,000$. Employee jobs have been revised up by 18,000 ( 0.07 per cent), mainly due to benchmarking. This is offset by a downward revision of 36,000 ( 0.87 per cent) in self-employment jobs due to LFS reweighting.

\section{GB employee jobs}

Benchmarking to the Annual Business Inquiry

Each year, the GB short-term employee jobs series are aligned to successive benchmarks from ABI1 estimates, also released in December (see ONS 2008b). The revised benchmark for September 2006 and the provisional benchmark for September 2007 have revised WFJ back to the start of 2006 (for 2005 and earlier, ABI1 estimates refer to December). The benchmarking process has caused an upward revision to the level of employee jobs in September 2007 of around 40,000 (offset by other revisions to the employee jobs series described below).

Table 3 and Table 4 show the revisions to WFJ by industry. Benchmarking has caused upward revisions to some industries and downward revisions to others. The shortterm estimator tends to underestimate the change in employment, so growing industries tend to be revised upwards, for example, finance, real estate, renting and business services (sections J and $\mathrm{K}$ ), has been revised up by 52,000 in September 2007. The opposite is the case for declining industries, such as manufacturing.

In highly seasonal industries, such as retail, there is an additional impact from benchmarking. The short-term employer surveys (STES) and ABI1 ask for employment on the same date (midSeptember) but, in practice, businesses tend to use a later date for STES than ABI1. This is because STES is dispatched after ABI1 and also because STES collects turnover information (used for the shortterm output indicators), and so businesses 
Table 1

Workforce jobs:1,2 revisions to levels

United Kingdom

Thousands, seasonally adjusted

\begin{tabular}{|c|c|c|c|c|}
\hline & Workforce jobs & Employee jobs & $\begin{array}{r}\text { Self-employment } \\
\text { jobs }\end{array}$ & $\begin{array}{r}\text { Government-supported } \\
\text { trainees }\end{array}$ \\
\hline Mar 96 & -4 & 0 & -4 & 0 \\
\hline Jun 96 & -2 & 0 & -1 & 0 \\
\hline Sep 96 & 0 & 1 & -1 & 0 \\
\hline Dec 96 & -3 & -2 & -1 & 0 \\
\hline Mar 97 & -2 & 1 & -3 & 0 \\
\hline Jun 97 & -8 & 0 & -8 & 0 \\
\hline Sep 97 & -6 & 2 & -8 & 0 \\
\hline Dec 97 & -13 & -5 & -8 & 0 \\
\hline Mar 98 & -16 & -8 & -8 & 0 \\
\hline Jun 98 & -11 & -3 & -8 & 0 \\
\hline Sep 98 & -12 & -4 & -8 & 0 \\
\hline Dec 98 & -27 & -18 & -9 & 0 \\
\hline Mar 99 & -22 & -16 & -6 & 0 \\
\hline Jun 99 & -38 & -34 & -4 & 0 \\
\hline Sep 99 & -28 & -23 & -4 & 0 \\
\hline Dec 99 & -25 & -20 & -5 & 0 \\
\hline Mar 00 & -49 & -45 & -4 & 0 \\
\hline Jun 00 & -50 & -46 & -4 & 0 \\
\hline Sep 00 & -47 & -42 & -6 & 0 \\
\hline Dec 00 & -44 & -40 & -4 & 0 \\
\hline Mar 01 & -27 & -25 & -2 & 0 \\
\hline Jun 01 & -33 & -29 & -3 & 0 \\
\hline Sep 01 & -17 & -12 & -5 & 0 \\
\hline Dec 01 & -21 & -13 & -8 & 0 \\
\hline Mar 02 & -21 & -15 & -6 & 0 \\
\hline Jun 02 & -14 & -12 & -2 & 0 \\
\hline Sep 02 & -18 & -14 & -5 & 0 \\
\hline Dec 02 & -19 & -11 & -9 & 0 \\
\hline Mar 03 & -27 & -19 & -9 & 0 \\
\hline Jun 03 & -25 & -13 & -12 & 0 \\
\hline Sep 03 & -24 & -11 & -13 & 0 \\
\hline Dec 03 & -7 & 3 & -10 & 0 \\
\hline Mar 04 & -9 & 4 & -13 & 0 \\
\hline Jun 04 & -12 & -2 & -10 & 0 \\
\hline Sep 04 & -24 & -7 & -17 & 0 \\
\hline Dec 04 & -29 & -8 & -21 & 0 \\
\hline Mar 05 & -31 & -7 & -24 & 0 \\
\hline Jun 05 & -27 & -8 & -19 & 0 \\
\hline Sep 05 & -24 & 6 & -30 & 0 \\
\hline Dec 05 & -32 & -2 & -30 & 0 \\
\hline Mar 06 & -29 & -3 & -26 & 0 \\
\hline Jun 06 & -36 & -19 & -17 & 0 \\
\hline Sep 06 & -15 & 8 & -24 & 1 \\
\hline Dec 06 & -18 & 13 & -31 & 1 \\
\hline Mar 07 & -41 & -3 & -38 & 0 \\
\hline Jun 07 & -66 & -17 & -47 & -2 \\
\hline Sep 07 & -10 & 27 & -37 & 0 \\
\hline Dec 07 & -9 & 32 & -41 & 1 \\
\hline Mar 08 & -9 & 29 & -39 & 1 \\
\hline Jun 08 & -18 & 18 & -36 & 1 \\
\hline
\end{tabular}

Notes:

Source: Office for National Statistics

1 Workforce jobs figures are a measure of jobs rather than people. For example, if a person holds two jobs, each job will be counted in the workforce

jobs total. For this reason, self-employment jobs (which come from the LFS) will not equal the figures for self-employed persons from the LFS. Workforce jobs figures come from a variety of sources and, where possible, from the employer rather than the individual. Employee jobs (which is much the largest component of Workforce Jobs) come from quarterly surveys of employers carried out by ONS, and administrative sources. Self-employment jobs are provided by the LFS. Government-supported trainees are provided from administrative sources.

2 There are no revisions to HM Forces data over the period shown. 
Table 2

\section{Workforce jobs: ${ }^{1,2}$ revisions to annual changes}

United Kingdom

Thousands, seasonally adjusted

\begin{tabular}{lrrrr}
\hline & Workforce jobs & Employee jobs & $\begin{array}{r}\text { Self-employment } \\
\text { jobs }\end{array}$ & $\begin{array}{r}\text { Government-supported } \\
\text { trainees }\end{array}$ \\
\hline Jun 97 & -6 & 1 & -7 & 0 \\
Jun 98 & -3 & -3 & 0 & 0 \\
Jun 99 & -27 & -31 & 4 & 0 \\
Jun 00 & -12 & -12 & 0 & 0 \\
& & & & 0 \\
Jun 01 & 18 & 17 & 1 & 0 \\
Jun 02 & 18 & 17 & 1 & 0 \\
Jun 03 & -10 & -1 & -9 & 0 \\
Jun 04 & 13 & 2 & 0 \\
Jun 05 & & -6 & -9 & 0 \\
Jun 06 & -11 & 3 & -2 \\
Jun 07 & -9 & -12 & 11 & 3 \\
Jun 08 & -29 & 35 & & 0 \\
\hline
\end{tabular}

\section{Notes:}

Source: Office for National Statistics

1 See note 1 to Table 1

2 There are no revisions to HM Forces data over the period shown.

tend to wait until the turnover information is available before completing the employment section.

Therefore, STES estimates tend to be higher than ABI1, which causes downward revisions when the STES estimates are subsequently benchmarked to $\mathrm{ABI} 1$. The downward revision of around 60,000 in distribution, hotels and catering (sections $\mathrm{G}$ and $\mathrm{H}$, which contains the retail sector) is partly caused by this effect.

\section{Agriculture}

The LFS provides WFJ with the GB shortterm employee jobs series for agriculture, because this sector is not covered by STES. In May 2008, ONS revised LFS estimates due to reweighting the microdata (see Palmer and Hughes 2008), and again in October 2008 due to interim reweighting (reweighting the aggregate series to 2007 mid-year population estimates). These revisions have now been applied to WFJ back to 1998Q1, that is, as far back as the first ABI1 benchmark in 1998.

The series is currently only benchmarked up to 2001 because of quality issues with the ABI1 estimates after this period. The 2000 and 2001 benchmarks have now been updated in line with published estimates for ABI1, but benchmarks thereafter will not be applied until the ABI1 team have completed quality assurance of their estimates.

These changes have caused predominantly upward revisions from 2002 onwards and downwards revisions before then, particularly in 2000 .

\section{Construction}

The LFS also provides WFJ with the GB short-term employee jobs series for construction, again because this sector is not covered by STES. ONS has recently taken over responsibility for the construction employer surveys from the Department for Business, Enterprise \& Regulatory Reform (BERR), and is aiming to use this as the source for short-term employee jobs in construction in place of the LFS, once the surveys have been fully transferred and redeveloped. Therefore, the LFS reweighting revisions have only been taken on back to 2006Q1, that is, as far back as the revisions caused by benchmarking.

\section{Public sector employment}

For those industries which have a significant proportion of jobs in the public sector, WFJ uses ONS's public sector employment (PSE) estimates for GB (see ONS 2008c), that is, for public administration and defence, education, health and social work (sections L, M and $\mathrm{N}$ ), post and telecommunications (division 64) and recreation, cultural and sporting activities (division 92). These inputs are not benchmarked as they are the definitive measure of PSE. However, PSE estimates are also revised in December, and so these revisions are applied to WFJ inputs. These revisions go back to 1998Q4 and, for recent periods, total approximately $-20,000$, and are predominantly in sections $\mathrm{L}, \mathrm{M}$ and $\mathrm{N}$.

\section{GB self-employed jobs}

The LFS is used as the measure of selfemployment jobs. Again, LFS reweighting revisions have been applied to these series. This has caused downward revisions of up to 47,000 in June 2007 , tapering back to 1995Q1.

\section{Government-supported trainees}

The Department for Innovation, Universities and Skills and the devolved administrations provide the information for these series; small revisions have been taken on.

\section{Northern Ireland jobs}

WFJ estimates for Northern Ireland are provided by the Department of Enterprise, Trade and Investment in Northern Ireland, which has revised its series back to 1995Q1, mainly due to LFS reweighting.

\section{Seasonal adjustment}

Seasonal adjustment is performed at various levels of aggregation. Revising the non-seasonally adjusted series causes revisions to the seasonal factors.

The comparison of WFJ and LFS estimates of jobs, shown in Annex 1 of the Labour Market Overview (see ONS 2008d) that accompanies the First Release, has been updated to reflect revisions to both measures.

\section{CONTACT}

elmr@ons.gsi.gov.uk

\section{REFERENCES}

Office for National Statistics (2008b) 'Annual Business Inquiry (ABI/1) employee jobs estimates' at

www.nomisweb.co.uk

Office for National Statistics (2008d)

'Comparison of LFS and WFJ statistics on jobs' at

www.statistics.gov.uk/statbase/product. asp?vlnk=1944

Office for National Statistics (2008a) 'Labour Market Statistics First Release - December 2008' at

www.statistics.gov.uk/statbase/product. asp? vlnk=1944

Office for National Statistics (2008c) 'Public Sector Employment First Release - Q3 2008' at www.statistics.gov.uk/statbase/product. asp?vlnk=13615

Palmer N and Hughes M (2008) 'Labour Force Survey: reweighting and seasonal adjustment review 2008', Economic \& Labour Market Review 2(6), pp 33-42 and at www.statistics.gov.uk/cci/article.asp?id= 2011 
Table 3

Workforce jobs: ${ }^{1}$ by industry, revisions to levels

United Kingdom

Thousands, seasonally adjusted

\begin{tabular}{|c|c|c|c|c|c|c|c|c|c|}
\hline \multirow{2}{*}{$\begin{array}{l}\text { SIC } 2003 \\
\text { sections }\end{array}$} & \multirow{2}{*}{$\begin{array}{r}\text { All jobs } \\
\text { A-0 }\end{array}$} & \multirow{2}{*}{$\begin{array}{r}\begin{array}{r}\text { Agriculture and } \\
\text { fishing }\end{array} \\
A, B \\
\end{array}$} & \multirow{2}{*}{$\begin{array}{r}\text { Production } \\
\mathrm{C}-\mathrm{E} \\
\end{array}$} & \multirow{2}{*}{$\begin{array}{r}\text { Construction } \\
\mathrm{F}\end{array}$} & \multicolumn{2}{|c|}{$\begin{array}{l}\text { Distribution, } \\
\text { hotels and Transport and } \\
\text { Catering communications }\end{array}$} & \multirow{2}{*}{$\begin{array}{r}\begin{array}{r}\text { Finance, real } \\
\text { estate, renting } \\
\text { and business } \\
\text { activities }\end{array} \\
\mathrm{J}, \mathrm{K} \\
\end{array}$} & \multirow{2}{*}{$\begin{array}{r}\begin{array}{r}\text { Public } \\
\text { administration, } \\
\text { education and } \\
\text { health }\end{array} \\
\mathrm{L}-\mathrm{N} \\
\end{array}$} & \multirow{2}{*}{ Other services } \\
\hline & & & & & $\mathrm{G}, \mathrm{H}$ & I & & & \\
\hline Mar 96 & -4 & 1 & -2 & -3 & 4 & 1 & 1 & -2 & -3 \\
\hline Jun 96 & -2 & 2 & 1 & 3 & -1 & -1 & -6 & -1 & 1 \\
\hline Sep 96 & 0 & -1 & 0 & 0 & -2 & -2 & 1 & 2 & 0 \\
\hline Dec 96 & -3 & -5 & 0 & -4 & -2 & 0 & 3 & 2 & 3 \\
\hline Mar 97 & -2 & 4 & -1 & 2 & 0 & -11 & -13 & 15 & 2 \\
\hline Jun 97 & -8 & 3 & 1 & -9 & -11 & -4 & 3 & 5 & 5 \\
\hline Sep 97 & -6 & 2 & -7 & -14 & 0 & 8 & -1 & 0 & 7 \\
\hline Dec 97 & -13 & -5 & 0 & -8 & 5 & 0 & -17 & 1 & 12 \\
\hline Mar 98 & -16 & -10 & -4 & -10 & -4 & 2 & 2 & 6 & 3 \\
\hline Jun 98 & -11 & 0 & -4 & -29 & 3 & 4 & 8 & -6 & 13 \\
\hline Sep 98 & -12 & -5 & 11 & -13 & -9 & -4 & -4 & 8 & 4 \\
\hline Dec 98 & -27 & -3 & -4 & -15 & 1 & -9 & -1 & -11 & 15 \\
\hline Mar 99 & -22 & -7 & 8 & -24 & -11 & 4 & -4 & -10 & 22 \\
\hline Jun 99 & -38 & -9 & 2 & -6 & -4 & -2 & -3 & -8 & -8 \\
\hline Sep 99 & -28 & -13 & -2 & -14 & 15 & -8 & 0 & -11 & 4 \\
\hline Dec 99 & -25 & -9 & -5 & -11 & -1 & -4 & -6 & -9 & 19 \\
\hline Mar 00 & -49 & -31 & 0 & -6 & -10 & -4 & 15 & -3 & -9 \\
\hline Jun 00 & -50 & -32 & 3 & -10 & 2 & -4 & -10 & -15 & 15 \\
\hline Sep 00 & -47 & -36 & -3 & -10 & -9 & -8 & 11 & -8 & 15 \\
\hline Dec 00 & -44 & -19 & -1 & -20 & -15 & 1 & -7 & 6 & 11 \\
\hline Mar 01 & -27 & -14 & -2 & -19 & 11 & -3 & 4 & -14 & 10 \\
\hline Jun 01 & -33 & -18 & 4 & -16 & 5 & -7 & -10 & -2 & 12 \\
\hline Sep 01 & -17 & 2 & -3 & -8 & 1 & -1 & -1 & -8 & -1 \\
\hline Dec 01 & -21 & -7 & 3 & -17 & 14 & -8 & -2 & -19 & 15 \\
\hline Mar 02 & -21 & 0 & 5 & -17 & -7 & 1 & -6 & -3 & 4 \\
\hline Jun 02 & -14 & 9 & -4 & -23 & -4 & -3 & 19 & -15 & 5 \\
\hline Sep 02 & -18 & 9 & -4 & -20 & -2 & -6 & 12 & -27 & 20 \\
\hline Dec 02 & -19 & -1 & 3 & -6 & 1 & -4 & -10 & -9 & 8 \\
\hline Mar 03 & -27 & 3 & -1 & -17 & 7 & 5 & -5 & -18 & 0 \\
\hline Jun 03 & -25 & 3 & 2 & -4 & -12 & 0 & 8 & -14 & -8 \\
\hline Sep 03 & -24 & -1 & -5 & -21 & 1 & -3 & 15 & -12 & 1 \\
\hline Dec 03 & -7 & 15 & 9 & -25 & 8 & -12 & -8 & -8 & 14 \\
\hline Mar 04 & -9 & 19 & 0 & -13 & -16 & -5 & 6 & -6 & 6 \\
\hline Jun 04 & -12 & 9 & 0 & -21 & 1 & 0 & -5 & -13 & 17 \\
\hline Sep 04 & -24 & 3 & 7 & -11 & -6 & 2 & -13 & -15 & 10 \\
\hline Dec 04 & -29 & 2 & -1 & -2 & -10 & -2 & 5 & -18 & -3 \\
\hline Mar 05 & -31 & 10 & -1 & -4 & -5 & 1 & -13 & -19 & 0 \\
\hline Jun 05 & -27 & 11 & -2 & 0 & -5 & -2 & -17 & -11 & -1 \\
\hline Sep 05 & -24 & 7 & -5 & -5 & 2 & -4 & -5 & -15 & 0 \\
\hline Dec 05 & -32 & 9 & -1 & -1 & -12 & -4 & 0 & -22 & 0 \\
\hline Mar 06 & -29 & 16 & 0 & 0 & -8 & 3 & -14 & -24 & -2 \\
\hline Jun 06 & -36 & 11 & 0 & 4 & -11 & 4 & -16 & -26 & -3 \\
\hline Sep 06 & -15 & 11 & 3 & -6 & 0 & 8 & 0 & -30 & 0 \\
\hline Dec 06 & -18 & 13 & 6 & 6 & -32 & 9 & 11 & -24 & -6 \\
\hline Mar 07 & -41 & 19 & 2 & 4 & -44 & 16 & 11 & -30 & -17 \\
\hline Jun 07 & -66 & 8 & -6 & 14 & -61 & 14 & 15 & -26 & -25 \\
\hline Sep 07 & -10 & 12 & 3 & 19 & -59 & 16 & 52 & -22 & -30 \\
\hline Dec 07 & -9 & 13 & -2 & 27 & -67 & 19 & 53 & -26 & -26 \\
\hline Mar 08 & -9 & 17 & 0 & 30 & -64 & 17 & 40 & -19 & -29 \\
\hline Jun 08 & -18 & 16 & -7 & 38 & -69 & 13 & 35 & -14 & -30 \\
\hline
\end{tabular}

Notes:

1 See note 1 to Table 1

2 Includes both public and private sectors. 
Table 4

Workforce jobs: ${ }^{1}$ by industry, revisions to annual changes

United Kingdom

Thousands, seasonally adjusted

\begin{tabular}{|c|c|c|c|c|c|c|c|c|c|}
\hline \multirow{2}{*}{$\begin{array}{l}\text { SIC } 2003 \\
\text { sections }\end{array}$} & \multirow{2}{*}{$\begin{array}{r}\text { All jobs } \\
A-0\end{array}$} & \multirow{2}{*}{$\begin{array}{r}\begin{array}{r}\text { Agriculture and } \\
\text { fishing }\end{array} \\
A, B \\
\end{array}$} & \multirow{2}{*}{$\begin{array}{r}\text { Production } \\
\mathrm{C}-\mathrm{E} \\
\end{array}$} & \multirow{2}{*}{$\begin{array}{r}\text { Construction } \\
\mathrm{F}\end{array}$} & \multicolumn{2}{|c|}{$\begin{array}{r}\text { Distribution, } \\
\text { hotels and Transport and } \\
\text { Catering communications }\end{array}$} & \multirow[t]{2}{*}{$\begin{array}{r}\text { Finance, real } \\
\text { estate, renting } \\
\text { and business } \\
\text { activities } \\
\text { J,K }\end{array}$} & \multirow{2}{*}{$\begin{array}{r}\begin{array}{r}\text { Public } \\
\text { administration, } \\
\text { education and } \\
\text { health }\end{array} \\
\mathrm{L}-\mathrm{N} \\
\end{array}$} & \multirow{2}{*}{ Other service } \\
\hline & & & & & $\mathrm{G}, \mathrm{H}$ & $\mathrm{I}$ & & & \\
\hline Jun 97 & -6 & 1 & 0 & -13 & -10 & -4 & 9 & 6 & 5 \\
\hline Jun 98 & -3 & -3 & -5 & -19 & 14 & 9 & 5 & -11 & 8 \\
\hline Jun 99 & -27 & -9 & 6 & 22 & -7 & -7 & -10 & -1 & -21 \\
\hline Jun 00 & -12 & -22 & 1 & -3 & 6 & -2 & -7 & -8 & 23 \\
\hline Jun 01 & 18 & 13 & 1 & -6 & 3 & -3 & 0 & 13 & -3 \\
\hline Jun 02 & 18 & 28 & -8 & -7 & -9 & 5 & 29 & -13 & -6 \\
\hline Jun 03 & -10 & -6 & 6 & 19 & -8 & 2 & -11 & 1 & -13 \\
\hline Jun 04 & 13 & 6 & -2 & -16 & 12 & 0 & -13 & 1 & 25 \\
\hline Jun 05 & -15 & 2 & -2 & 21 & -5 & -3 & -11 & 2 & -18 \\
\hline Jun 06 & -9 & 0 & 2 & 4 & -6 & 6 & 1 & -15 & -2 \\
\hline Jun 07 & -29 & -3 & -6 & 10 & -50 & 11 & 31 & 0 & -21 \\
\hline Jun 08 & 48 & 8 & -1 & 24 & -8 & -2 & 20 & 12 & -5 \\
\hline
\end{tabular}

Notes:

Source: Office for National Statistics

1 See note 1 to Table 1.

2 Includes both public and private sectors. 